\title{
Total Synthesis of cis,cis-Ceratospongamide, a Bioactive Thiazole-Containing Cyclic Peptide from Marine Origin
}

\author{
Fumiaki Yokokawa,* Hirofumi Sameshima, Takayuki Shioiri* \\ Faculty of Pharmaceutical Sciences, Nagoya City University, Tanabe-dori, Mizuho-ku, Nagoya 467-8603, Japan \\ Fax +81 (52) 8344172; E-mail: shioiri@ phar.nagoya-cu.ac.jp \\ Received 30 January 2001 \\ Dedicated to Professor Ryoji Noyori in recognition of his remarkable contributions to modern asymmetric synthesis
}

\begin{abstract}
The first total synthesis of cis,cis-ceratospongamide (1a), isolated from marine source, was accomplished via thiazole synthesis using CMD methodology, DEPC-mediated peptide coupling, macrolactamization, and cyclodehydration. Comparison of the cyclization sites and coupling reagents in the macrolactamization step was also investigated.
\end{abstract}

Key words: ceratospongamide, chemical manganese dioxide (CMD), macrolactamization, cyclic peptide, total synthesis

Ceratospongamide is a bioactive thiazole-containing cyclic heptapeptide isolated by Gerwick and co-workers from the Indonesian red alga Ceratodictyon spongiosum and symbiotic sponge Sigmadocia symbiotica. ${ }^{1}$ This peptide consists of two $L$-phenylalanine residues, one ( $L$-isoleucine)-L-methyloxazoline residue, one $L$-proline residue, and one ( $L$-proline)thiazole residue. Interestingly, ceratospongamide is able to be isolated as two stable isomers, which are assigned as cis,cis-and trans,trans-isomers $(\mathbf{1 a}, \mathbf{1 b})$ of the two proline amide bonds by Gerwick and co-workers (Figure 1). Both compounds show moderate potency in the brine shrimp toxicity assay $\left(\mathrm{LD}_{50}=13\right.$ $19 \mu \mathrm{M})$. In addition, trans,trans-ceratospongamide (1b) exhibits potent inhibition of the expression of a key enzyme in the inflammatory cascade, secreted phospholi-

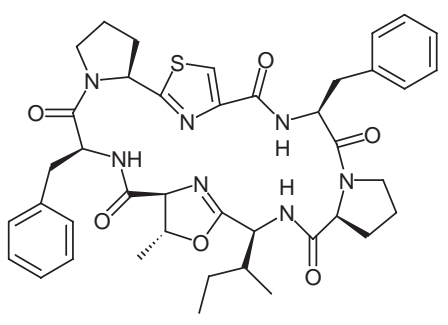

cis, cis-Ceratospongamide (1a)

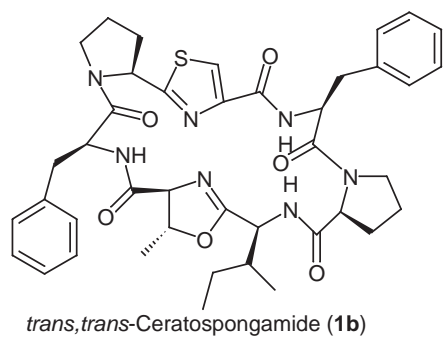

Figure

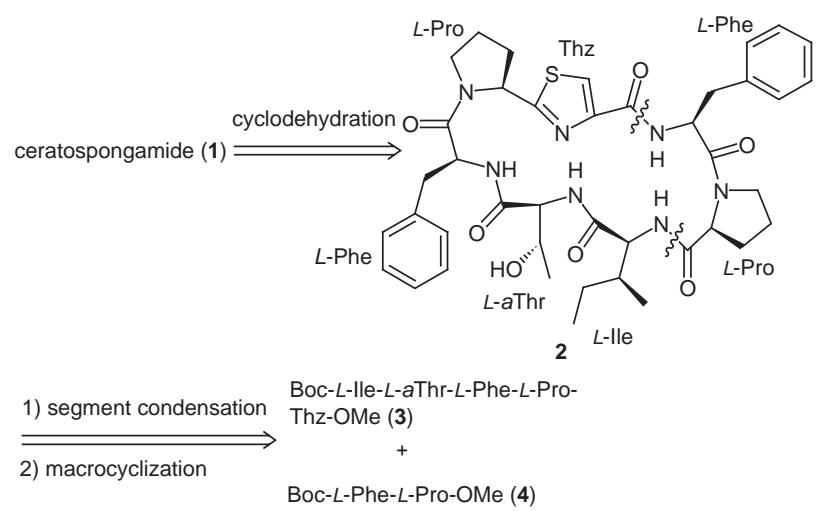

Scheme 1 Retrosynthetic analysis of ceratospongamide

pase $\mathrm{A}_{2}\left(\mathrm{sPLA}_{2}\right)$ with an $\mathrm{ED}_{50}$ of $32 \mathrm{nM}$, whereas the cis,cis-conformer (1a) is inactive. As a part of our program toward the total synthesis of marine natural products, ${ }^{2}$ we have embarked on the total synthesis of ceratospongamide. ${ }^{3}$

Our retrosynthetic analysis of ceratospongamide is shown in Scheme 1. As the oxazoline ring is sensitive under acidic conditions, we used allo-L-threonine as a precursor of the oxazoline and postponed the cyclodehydration of the threonine residue to the final stage of the total synthesis for reducing the risk of racemization at the chiral center attached to the heterocycle. ${ }^{4}$ For the synthesis of the macrocycle 2 , a [5+2] convergent strategy was adopted to give the pentapeptide segment 3 and dipeptide segment 4 . Because the thiazole and L-proline residues located on the Cterminus in peptide coupling would be tolerant of racemization, the segment condensation and macrocyclization at the thiazole $/ L$-phenylalanine and $L$-proline $/ L$-isoleucine amide bonds were chosen among the six amide bonds.

For the preparation of the thiazole amino acid fragment $\mathbf{8}$, we applied our CMD (chemical manganese dioxide) oxidation for the conversion of thiazolidine to thiazole (Scheme 2) ${ }^{3 \mathrm{~b}, 5}$ Coupling of Boc-protected $L$-proline with $\mathrm{N}, \mathrm{O}$-dimethylhydroxylamine using DEPC (diethyl phosphorocyanidate $)^{6}$ afforded the amide 5 in $88 \%$ yield. After reduction of the amide $\mathbf{5}$ with lithium aluminum hydride, ${ }^{7}$ the resulting aldehyde $\mathbf{6}$ was condensed with $L$-cysteine methyl ester to give the thiazolidine $\mathbf{7}$ as a diastereomeric 


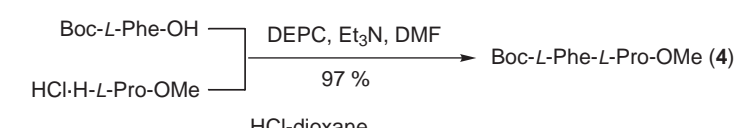

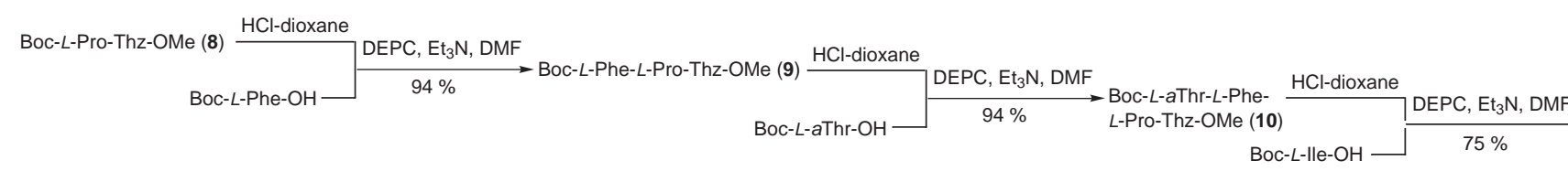
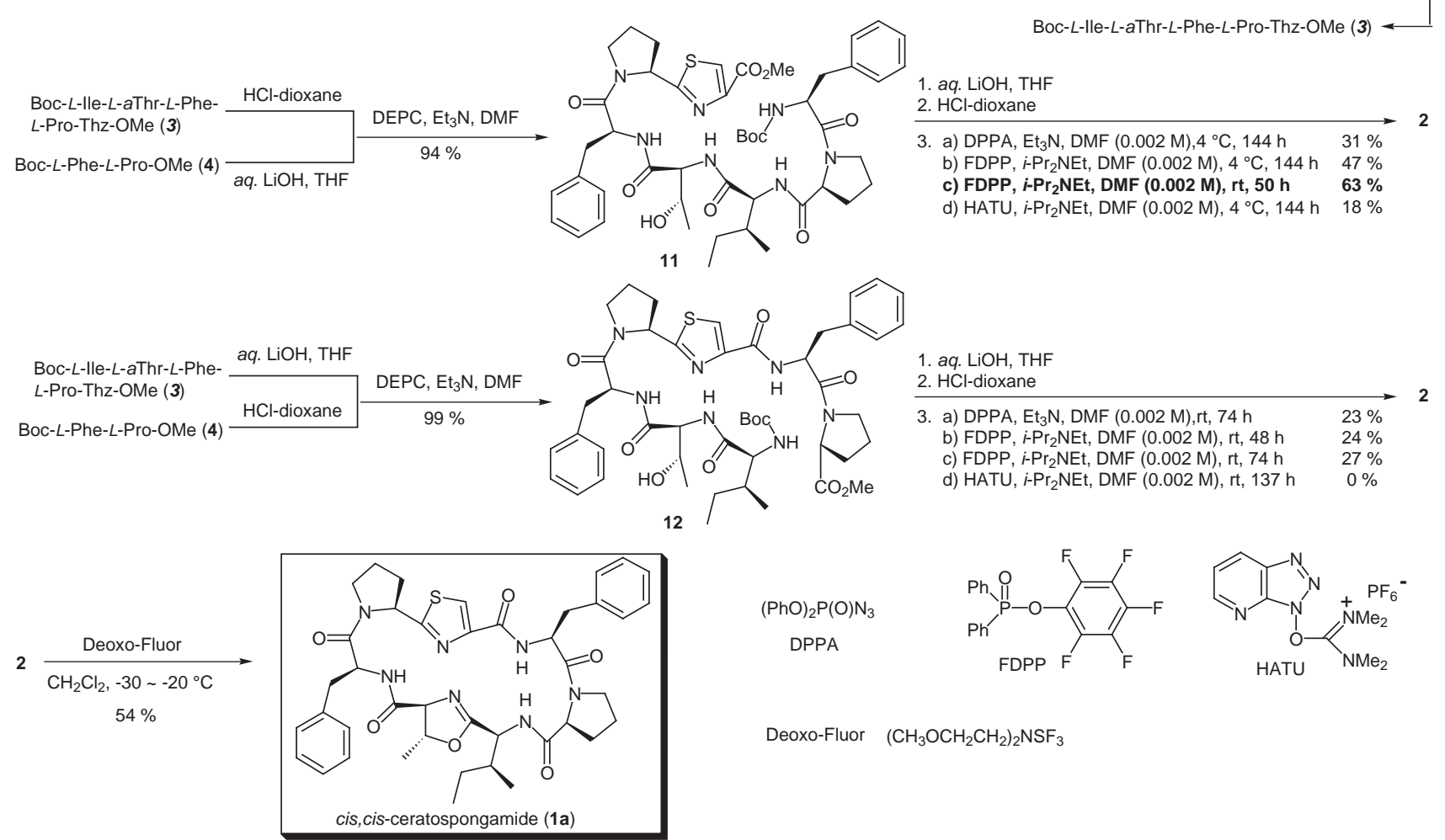

Deoxo-Fluor $\quad\left(\mathrm{CH}_{3} \mathrm{OCH}_{2} \mathrm{CH}_{2}\right)_{2} \mathrm{NSF}_{3}$

Scheme 3 Total synthesis of cis,cis-ceratospongamide (1a)

mixture in $73 \%$ yield. Subsequent CMD oxidation of the thiazolidine $\mathbf{7}$ provided the thiazole fragment $\mathbf{8}$ in $51 \%$ yield.
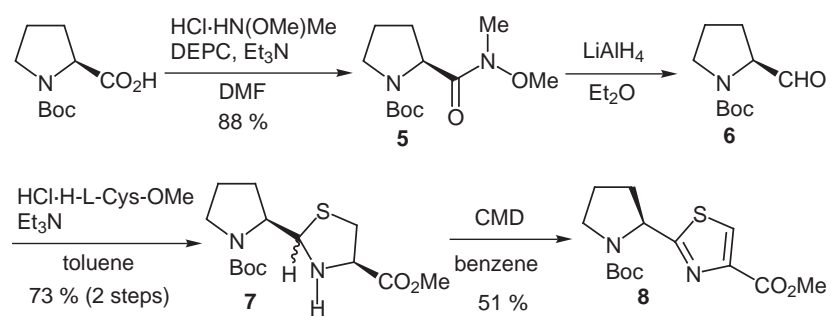

Scheme 2 Synthesis of Boc-L-Pro-Trz-OMe

The dipeptide segment $\mathbf{4}$ was obtained by coupling of Boc-protected $L$-phenylalanine with $L$-proline methyl ester using DEPC in $97 \%$ yield (Scheme 3). For the preparation of the pentapeptide segment 3 , removal of the Boc protective group of the thiazole fragment $\mathbf{8}$ with hydrogen chloride in dioxane followed by condensation with Bocprotected $L$-phenylalanine using DEPC in $94 \%$ yield. Iter- ative removal of the Boc protective group followed by peptide coupling with the Boc derivatives of L-allo-threonine and $L$-isoleucine led to the pentapeptide segment $\mathbf{3}$. After acidic deprotection of the Boc group of $\mathbf{3}$, segment condensation with the acid derived from the dipeptide $\mathbf{4}$ proceeded smoothly to give the fully protected heptapeptide 11 in $94 \%$ yield (Scheme 3). Similarly, deprotection of the Boc group of $\mathbf{4}$ and segment condensation with the acid derived from 3 also afforded the other linear precursor 12 in $99 \%$ yield. The stage was now set for the comparison of macrolactamization step at two sites (Thz/Phe vs. Pro/Ile). After deprotection of the Boc group in $\mathbf{1 1}$ and 12 with hydrogen chloride in dioxane and saponification of the methyl ester with lithium hydroxide, macrolactamizations of the resulting two free linear precursors were performed in a DMF solution $(0.002 \mathrm{M})$ by using DPPA (diphenyl phosphorazidate), ${ }^{8}$ FDPP (pentafluorophenyl diphenylphosphinate $),{ }^{9}$ and HATU $[O$-(7-azabenzotriazol-1-yl)- $N, N, N^{\prime}, N^{\prime}$ '-tetramethyluronium hexafluorophosphate] ${ }^{10}$ respectively. The cyclization at the Thz/Phe site proceeded smoothly and the yield by FDPP was higher than those by DPPA and HATU. In contrast, the cyclization at Pro/Ile site was sluggish to proceed, and especially 
no cyclized product was obtained by use of HATU. Accordingly, we carried out the macrolactamization at the Thz/Phe site with 1.5 equivalents of FDPP and 4 equivalents of $i$ - $\operatorname{Pr}_{2} \mathrm{NEt}$ at room temperature to give the cyclic peptide 2 in $63 \%$ yield from the corresponding linear precursor 11. Finally, cyclodehydration of the allo-threonine residue with bis(2-methoxyethyl)aminosulfur trifluoride (Deoxo-fluor) to the oxazoline ${ }^{11}$ produced the target compound, which was completely identical with natural cis,cis-ceratospongamide (1a) as judged by ${ }^{1} \mathrm{H}$ and ${ }^{13} \mathrm{C}$ NMR spectra, HPLC, and TLC $R_{f}$ values (Scheme 3).

In conclusion, we have developed an efficient strategy toward the total synthesis of cis,cis-ceratospongamide. The conversion of synthetic cis, cis-ceratospongamide (1a) to its trans,trans-isomer (1b) is currently underway.

\section{Acknowledgement}

We thank Prof. W. H. Gerwick and Mr. L. T. Tan for comparison of our synthetic cis,cis-ceratospongamide with the natural sample. This work was financially supported in part by Grant-in-Aid for Research in Nagoya City University (to F.Y.), Uehara Memorial Foundation (to F.Y.), and Grant-in-Aids from the Ministry of Education, Science, Sports and Culture, Japan.

\section{References and Notes}

(1) Tan, L. T., Williamson, R. T., Gerwick, W. H., Watts, K. S., McGough, K., Jacobs, R. J. Org. Chem. 2000, 65, 419-425.

(2) (a) Yokokawa, F.; Fujiwara, H.; Shioiri, T. Tetrahedron 2000, 56, 1759-1775. (b) Sugiyama, H.; Yokokawa, F.; Shioiri, T. Org. Lett. 2000, 2, 2149-2152. (c) Wu, M.; Okino, T.; Nogle, L. M.; Marquez, B. L.; Williamson, R. T.; Sitachitta, N.; Berman, F. W.; Murray, T. F.; McGough, K.; Jacobs, R.;
Colsen, K.; Asano, T.; Yokokawa, F.; Shioiri, T.; Gerwick, W. H. J. Am. Chem. Soc. 2000, 122, 12041-12042. (d) Yokokawa, F.; Asano, T.; Shioiri, T. Org. Lett. 2000, 2, 4169-4172.

(e) For a review, see Shioiri, T.; Hamada, Y. Synlett 2001, 184-201.

(3) A part of this work was presented at 37th Japanese Peptide Symposium, Nagoya, Oct 18-20, 2000. See Yokokawa, F.; Sameshima, H.; Shioiri, T. Peptide Science 2000, 2001, 5558.

(4) See: Shioiri, T.; Hamada, Y. Studies in Natural Products Chemistry; Atta-ur-Rahman, Ed.; Elsevier: Amsterdam 1989; Vol. 4 (Part C), pp 83-110.

(5) (a) Hamada, Y., Shibata, M., Sugiura, T., Kato, S., Shioiri, T. J. Org. Chem. 1987, 52, 1252-1255. (b) Aoyama, T., Sonoda, N., Yamauchi, M., Toriyama, K., Anzai, A., Ando, A., Shioiri, T. Synlett 1998, 35-36. (c) Fujiwara, H., Tojiki, K., Yokokawa, F., Shioiri, T. Peptide Science 1999 2000, 9-12.

(6) Takuma, S., Hamada, Y., Shioiri, T. Chem. Pharm. Bull. 1982, 30, 3147-3153 and references therein.

(7) Fehrentz, J.-A., Castro, B. Synthesis 1983, 676-678.

(8) Shioiri, T., Ninomiya, K., Yamada, S. J. Am. Chem. Soc. 1972, 94, 6203-6205.

(9) (a) Chen, S., Xu, J. Tetrahedron Lett. 1991, 32, 6711-6714. (b) Dudash, J., Jr., Jiang, J., Mayer, S. C., Joullie, M. M. Synth. Commun. 1993, 23, 349-356. (c) Deng, J.; Hamada, Y.; Shioiri, T.; Matsunaga, S.; Fusetani, N. Angew. Chem. Int. Ed. Engl. 1994, 33, 1729-1731. (d) Deng, J.; Hamada, Y.; Shioiri, T. Synthesis 1998, 627-638.

(10) Ehrlich, A., Heyne, H.-U., Winter, R., Beryermann, M., Haber, H., Carpino, L. A., Bienert, M. J. Org. Chem. 1996, 61, 8831-8838.

(11) Phillips, A. D., Uto, Y., Wipf, P., Reno, M. J., Williams, D. R. Org. Lett. 2000, 2, 1165-1168.

Article Identifier:

1437-2096,E;2001,0,SI,0986,0988,ftx,en;Y03501ST.pdf 